\title{
Avifaunal Diversity in Urban Coastal Wetland of Colombo Sri Lanka
}

\author{
Ethauda Arachchige Kasunthi Kisagothami Amarasekara*, Hewawasam Bentotage Jayasiri, \\ Champa Amarasiri
}

Faculty of Engineering and Management, Department of Coastal and Marine Resources Management, Ocean University of Sri Lanka, Colombo, Sri Lanka

Email: ${ }^{\star K}$ asunthiA@ocu.ac.lk

How to cite this paper: Amarasekara, E.A.K.K., Jayasiri, H.B. and Amarasiri, C. (2021) Avifaunal Diversity in Urban Coastal Wetland of Colombo Sri Lanka. Open Access Library Journal, 8: e7256. https://doi.org/10.4236/oalib.1107256

Received: February 20, 2021

Accepted: March 13, 2021

Published: March 16, 2021

Copyright $\odot 2021$ by author(s) and Open Access Library Inc.

This work is licensed under the Creative Commons Attribution International License (CC BY 4.0).

http://creativecommons.org/licenses/by/4.0/

(c) (i) Open Access

\begin{abstract}
Sri Lanka is an island nation, exhibiting remarkable biological diversity in spite of its small size; Country has rich ecosystem diversity because of its topographic and climatic heterogeneity as well as its coastal influence. The wetland ecosystems in Sri Lanka have been internationally recognized for their outstanding biological prosperity and their conservation status. Sri Lanka's wetlands are also diverse, comprised of 103 major rivers and associated marshes, and about 12,000 irrigation tanks harboring wetland species including inland and coastal wetland ecosystems which are even coming under Ramsar Wetland Sites. One such coastal wetland ecosystem in Sri Lanka is Crow Island coastal ecosystem. The Crow Island Beach Park is a public park located in Colombo-15 ( $\left.6^{\circ} 58^{\prime} 24.1^{\prime \prime} \mathrm{N}, 79^{\circ} 52^{\prime} 09.9^{\prime \prime} \mathrm{E}\right)$. The land extent of this park is 7 ha. The beach park consists of rich avifaunal diversity since it is a coastal wetland. Sri Lanka has been recognized as a country with "important Bird areas", a "key Asian region for threatened birds" and an "Endemic Bird Area". The main objective of the present study was to document the avifaunal diversity of the coastal wetland of the beach park. Multiple surveys were conducted through random visits in the area for a period of two months from July to August 2020. Their status was evaluated from the National Red List. Diurnal and nocturnal observations were made through the unaided eye and using a binocular via multiple random walks and point counting method. A total of 28 bird species were recorded belonging to 14 orders and 22 families representing 5.69\% of the birds recorded in Sri Lanka (492). Of the reported bird families, nine families represented Order Passeriformes while four species of birds found in the park represented family Ardeidae. This park is not only significant for biodiversity conservation but also for its value as a coastal wetland. The local community of the area is constantly interacting with the area for their living and for leisure. Consequently, these habitats are threatened by irresponsible human activities, such as garbage dumping, noise pol-
\end{abstract}


lution, lighting fires for garbage burning, clearing of natural vegetation in and around wetlands. However, detailed survey has to be carried out to study the abundance, seasonal variation to recommend the conservation and management measures.

\section{Subject Areas}

Ecology, Environmental Sciences

\section{Keywords}

Coastal Wetland, Avifaunal Diversity, Biodiversity Conservation

\section{Introduction}

Despite its small size, Sri Lanka has a rich ecosystem diversity because of its topographic and climatic heterogeneity as well as its coastal influence. There is a wide array of inland and coastal wetland ecosystems that harbor a rich biological diversity (Gunatilleke et al., 2008) [1]. Wetlands are defined by the Ramsar Convention on Wetlands as follows "Wetlands are areas of marsh, fen, peatland or water, whether natural or artificial, permanent or temporary, with water that is static or flowing, fresh, brackish or salt, including areas of marine water, the depth of which at low tides does not exceed six meters" (Ramsar, 1971) [2]. Wetlands are amongst the most productive ecosystems in the world as well as Sri Lanka. Moreover, those wetlands have supplied to human communities, food, drinking water, building materials and countless other benefits, from the thousands of years. They also play a critical role in maintaining global biodiversity, partly through their rich productivity, which helps to support food chains, and partly through provision of habitats for specially adapted plant and animal species (National Wetland Directory of Sri Lanka, 2006) [3]. Colombo is the capital of Sri Lanka and it is also South Asia's only Wetland City under the Ramsar Convention since 2018 (The Ramsar Convention Secretariat, 2018) [4]. Over $55 \%$ of the world's population lived in cities closed to wetlands, and the vast majority of these cities, including Colombo, are located near the coast (The Ramsar Convention Secretariat, 2018) [4]. In the face of climate change and rising sea levels, these cities depend on wetlands for flood control and storm-water management. Urban wetlands are not merely animal habitats, natural parks, or gaps located inside a city (Hettiarachchi, 2014) [5]. Colombo is criss-crossed by canals which are connected to a system of lakes and wetlands that are collectively known as the Colombo Wetland Complex (CWC). Out of 22,680 ha of city area, 1900 ha (more than 8\%) are contiguous wetland areas, such as Beddagna, Thalawatugoda, Kimbulawela, Madiwela, Kolonnawa, Crow Island, Talangama Lake, and Beira Lake (IUCN Sri Lanka, 2004) [6].

This study is about one such urban coastal wetland in Sri Lanka, Crow Island coastal wetland ecosystem. The Crow Island Beach Park ecosystem is a public 
park located in Colombo-15 ( $\left.6^{\circ} 58^{\prime} 24.1^{\prime \prime N}, 79^{\circ} 52^{\prime} 09.9^{\prime \prime E}\right)$ close to Kelani River mouth. The land extent of this park is about 7 ha. This park is bordered by Indian Ocean and from the park can observe Colombo harbor (Environmental Screening Report, 2014) [7]. Sri Lanka is rich in avifaunal diversity with over 492 species of birds representing 20 orders and 76 families (Kotagama et al., 2006) [8]. Owing to this high diversity and endemism, Sri Lanka has been recognized as a country with "Important Bird Areas", a "key Asian region for threatened birds" and an "Endemic Bird Area" (Kaluthota and Kotagama, 2008) [9]. Therefore, it is imperative to document distribution, habitat association, threats and conservation measures on avifauna.

Various studies on ecology and distribution of birds of Sri Lanka have so far been conducted in and around many areas in the wet and dry zones of Sri Lanka. Studies on avifauna of the coastal wetland's areas are very rare. Several such studies so far done on Northern province of the country by Kandasamy et al., 2017 [10] and 2019 [11]. Wetland avifaunal diversity somewhat documented but for coastal wetland areas avifaunal diversity including water birds yet remain undocumented leading to gaps in knowledge of distribution of the birds. Further, the role of human altered landscapes in conservation of birds has been greatly neglected. In the face of rapid economic development and increasing human population, the extent of conservation lands is gradually reducing. It is essential to study the suitability of urban coastal semi-natural ecosystems such as coastal wetlands for protection and conservation purpose. With these points as foundation, we surveyed the Crow Island Beach park coastal wetland ecosystem to study its diversity and habitat associations for birds and to document the avifaunal diversity of the urban coastal wetland. Other than that, to check birds residing status from the National Red List including threats on birds and then to find out the actions and solutions that can be used for the conservation and management process which would be enhance the avifaunal diversity of the site, while continuing with harmless human activities in the area.

\section{Methodology}

The study site is situated in a western province of $\left(6^{\circ} 58^{\prime} 24.1^{\prime \prime} \mathrm{N}, 79^{\circ} 52^{\prime} 09.9^{\prime \prime} \mathrm{E}\right)$ Colombo 15. Area is identified as Crow Island situated in the coastal boundary in Mattakkuliya, Colombo North. The area is owned and managed by the Colombo Municipal Council. Boundaries of the beach park: from the north side borders by the Naval Base and the National Aquatic Resources Research and Development Agency Premises, from east side by neighboring houses and commercial area, from the south side borders by small lagoon and from the western side park is bordered by the Indian Ocean. Size of this beach park is approximately 7 ha (Environmental Screening Report, 2014) [7]. Even though this park area is very small its geography is highly differentiating since it is a coastal wetland. One side of the park is covered by sandy beach and other side is covered by mangrove swamp with mud, one end with a small lagoon because of that different habitat diversity of this area biodiversity of flora and fauna is very high. Pre- 
sently this beach park area consists of grass lands, open area (without trees and concreted), mangrove and swamp area, scrublands and commercial area with food and toy shops (Figure 1).

The bird survey in the Crow Island Beach Park was done for two months from July to August 2020. The survey techniques used included visual encounter surveys, multiple surveys through random visits. The survey was done during various time periods of the day using unaided eye, binoculars and direct observations. Diurnal and nocturnal observations were made through the unaided eye and using a binocular via multiple random walks and point counting method. The avifaunal species richness of seven distinct habitats types namely grasslands, open grounds, mangrove and swamp area, scrub forest, commercial area, aerial and waterbody within Crow Island beach park was recorded. The identification of birds was done using popular field guides (Harrison, 1999) [12].

\section{Results}

During the study period, a total of 30 bird species were recorded in the study area representing 15 orders and 24 families (Figure 2 and Table 1). This would make up nearly $6.09 \%$ of the Sri Lanka's total avifaunal diversity. Results showed scrub forest area harbored the highest number of species representing 20 species from the observed 30 species recorded in the study (Figure 3) percentage is about $29 \%$ followed by 14 species in mangrove and swamp areas of the beach park representing $20 \%$ from the all-birds species observed in the park. Aerial habitats had the lowest species number accounting only five species from the study area representing $7 \%$ of the total avifaunal diversity of the area. Water body area of the habitat recorded 10 species from the observed species from the park representing $14 \%$ of the total avifaunal diversity of the park and those species restricted to the aquatic habitat (Figure 4). Nine families and nine species from the recorded results represented order Passeriformes (Figure 2). Those

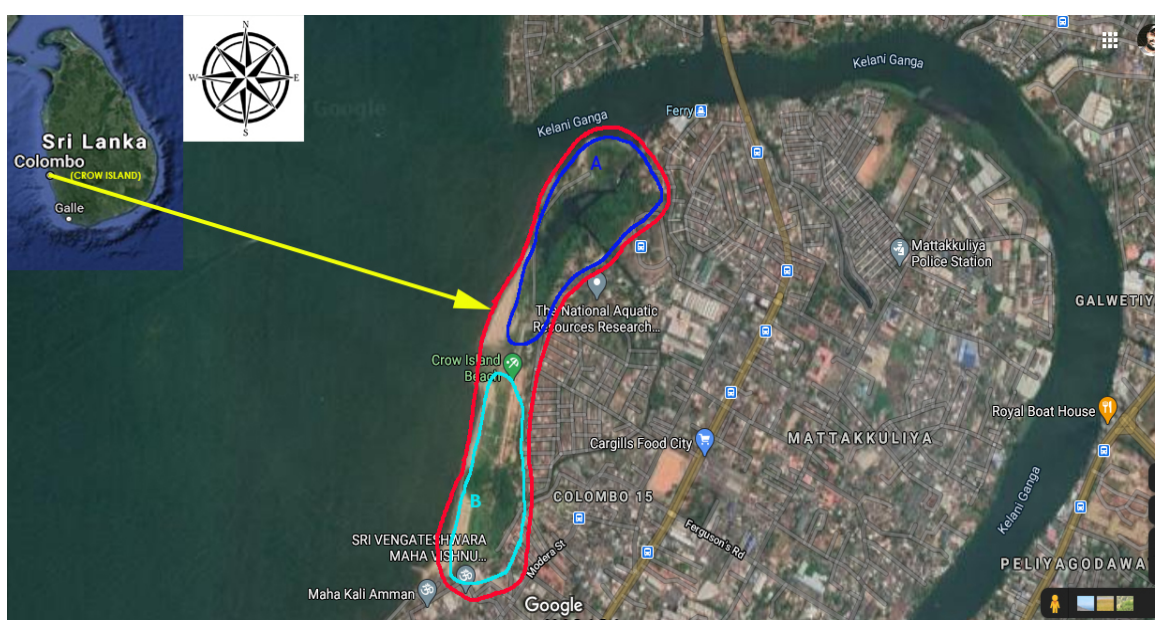

Figure 1. Satellite image of the study area-Crow Island Beach Park $\left(6^{\circ} 58^{\prime} 24.1^{\prime \prime} \mathrm{N}\right.$ $79^{\circ} 52^{\prime} 09.9^{\prime E}$ ) area mentioned by "A" small lagoon with opening to Kelani River, "B" mangrove swamp and grassland area. 


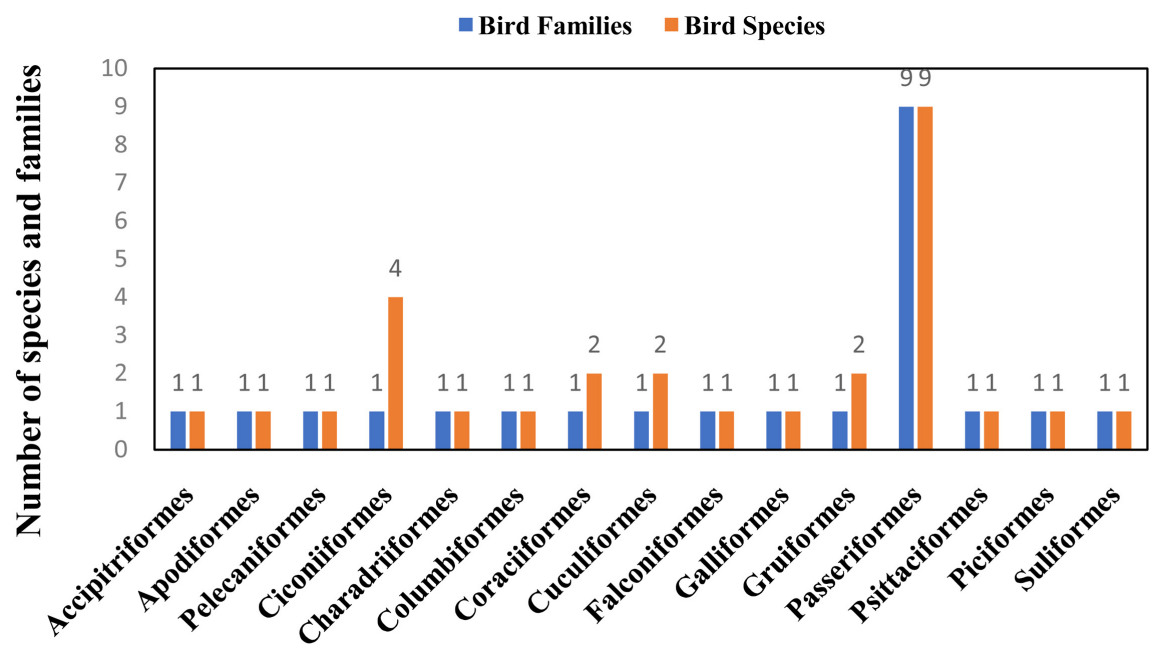

Orders

Figure 2. Number of bird families and species under the bird orders.

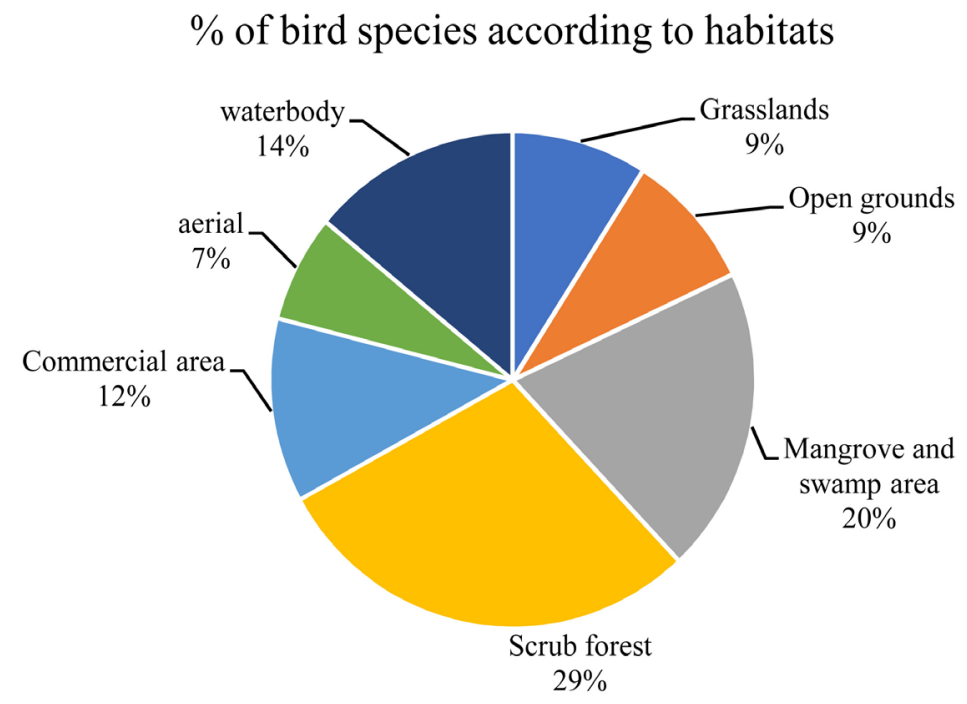

Figure 3. Percentage of bird species according to their habitats in the Crow Island beach park area.

families are Cisticolidae, Sturnidae, Corvidae, Tamaliidae, Sylviidae, Turdidae, Estrildidae, Dicruridae and Pycnonotidae for each of that families one species observed in the beach park. While four species of birds found in the park represented family Ardeidae (Table 1) that is the highest number of species from one family observed in the park and those species are water bird species namely Egretta garzetta, Ardea purpurea, Ardea cinereal, Ardeola grayii (Figure 4).

Species diversity of birds and their distribution with respect to available habitats can be clearly seen in Figure 3 and Table 1 including their category in the National Red list as well as their residential status. All the species found in the beach park during the study period are coming under least concern category of the National Red list and all species are breeding residents. 

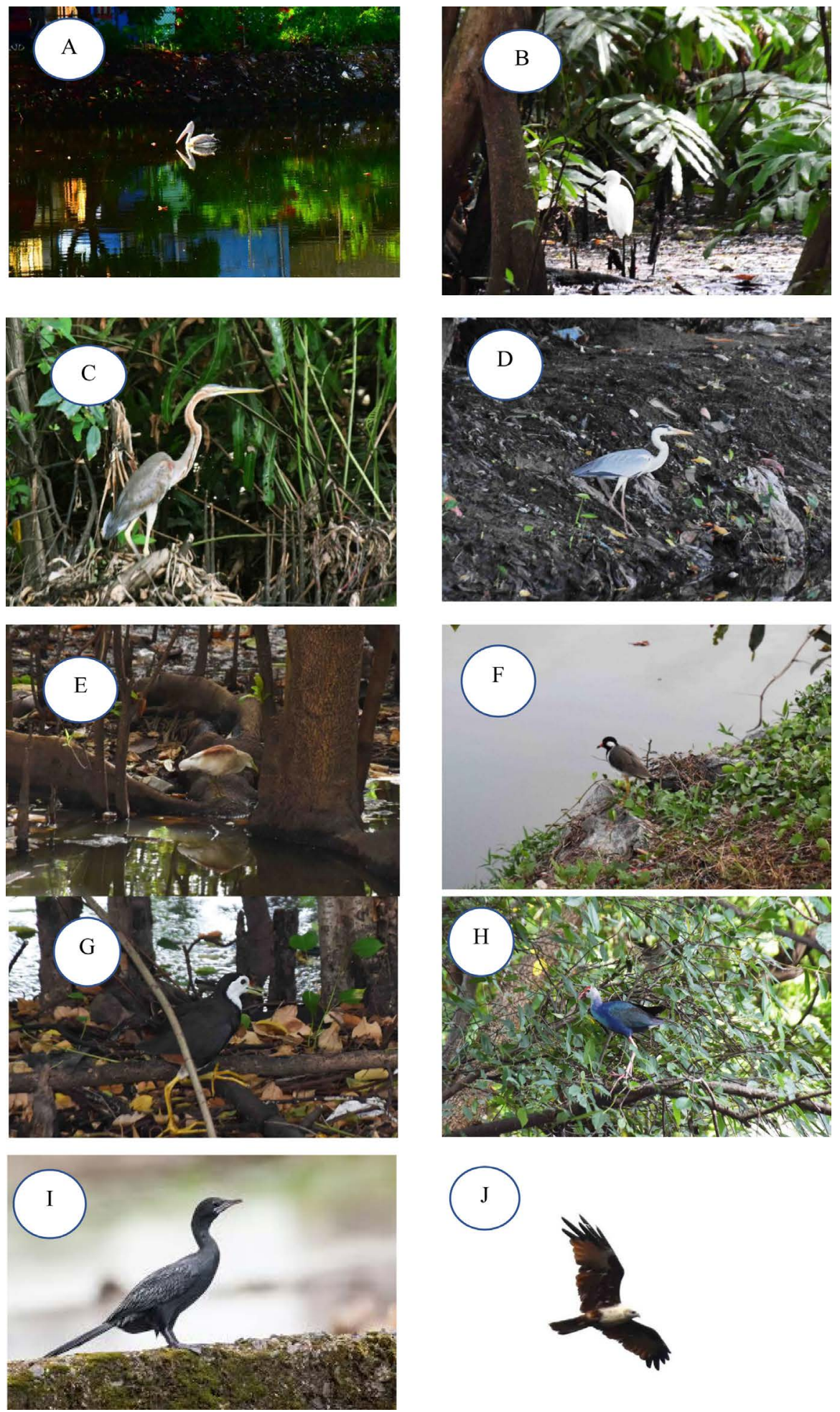

Figure 4. Water birds at Crow Island Beach park (A). Spot-billed Pelican (Pelecanus philippensis) (B). Little egret (Egretta garzetta) (C). Purple heron (Ardea purpurea) (D). Grey heron (Ardea cinereal) (E). Indian pond heron (Ardeola grayii) (F). Red-wattled lapwing (Vanellus indicus) (G). White-breasted waterhen (Amaurornis phoenicurus) (H). Purple swamphen (Porphyrio porphyrio) (I). Little comorant (Microcrabo niger) (J). Brahminy kite (Haliastur indus) not a water bird but common in the area. (Photos by V. Wijesekara). 
Table 1. Bird families and species recorded in the study with their status in red list and the residential status.

\begin{tabular}{|c|c|c|c|c|c|}
\hline No & Family & Species & Common Name & $\begin{array}{c}\text { IUCN Status } \\
2012\end{array}$ & $\begin{array}{c}\text { Residential } \\
\text { status }\end{array}$ \\
\hline 01 & Accipitridae & Accipiter trivirgatus & Crested goshawk & LC & $\mathrm{Br}$ \\
\hline 02 & Apodidae & Apus affinis & Little swift & $\mathrm{LC}$ & $\mathrm{Br}$ \\
\hline 03 & Pelicanidae & Pelecanus philippensis & Spot-billed Pelican & LC & $\mathrm{Br}$ \\
\hline \multirow[t]{4}{*}{04} & Ardeidae & Egretta garzetta & Little egret & $\mathrm{LC}$ & $\mathrm{Br}$ \\
\hline & & Ardea purpurea & Purple heron & LC & $\mathrm{Br}$ \\
\hline & & Ardea cinereal & Grey heron & LC & $\mathrm{Br}$ \\
\hline & & Ardeola grayii & Indian pond heron & $\mathrm{LC}$ & $\mathrm{Br}$ \\
\hline 05 & Charadriidae & Vanellus indicus & Red-wattled lapwing & $\mathrm{LC}$ & $\mathrm{Br}$ \\
\hline 06 & Scolopacidae & Actitis hypoleucos & Common Sandpiper & $\mathrm{LC}$ & $\mathrm{Br}$ \\
\hline 07 & Columbidae & Colomba livia & Rock pigeon & LC & $\mathrm{Br}$ \\
\hline \multirow[t]{2}{*}{08} & Alcedinidae & Halcyon smyrnensis & White-breasted kingfisher & $\mathrm{LC}$ & $\mathrm{Br}$ \\
\hline & & Pelargopsis capensis & Stork-billed kingfisher & LC & $\mathrm{Br}$ \\
\hline \multirow[t]{2}{*}{09} & Cuculidae & Eudynamus scolopacea & Asian koel & $\mathrm{LC}$ & $\mathrm{Br}$ \\
\hline & & Centropus sinensis & Greater coucal & $\mathrm{LC}$ & $\mathrm{Br}$ \\
\hline 10 & Accipitridae & Haliastur indus & Brahminy kite & $\mathrm{LC}$ & $\mathrm{Br}$ \\
\hline 11 & Phasianidae & Pavo cristatus & Common peafowl & $\mathrm{LC}$ & $\mathrm{Br}$ \\
\hline \multirow[t]{2}{*}{12} & Rallidae & Amaurornis phoenicurus & White-breasted waterhen & LC & $\mathrm{Br}$ \\
\hline & & Porphyrio porphyrio & Purple swamphen & $\mathrm{LC}$ & $\mathrm{Br}$ \\
\hline 13 & Cisticolidae & Cisticola juncidis & Zitting cisticola & $\mathrm{LC}$ & $\mathrm{Br}$ \\
\hline 14 & Sturnidae & Acridotheres tristis & Common Mynah & $\mathrm{LC}$ & $\mathrm{Br}$ \\
\hline 15 & Corvidae & Corvus splendens & House Crow & $\mathrm{LC}$ & $\mathrm{Br}$ \\
\hline 16 & Tamaliidae & Turdoides affinis & Yellow-billed Babbler & LC & $\mathrm{Br}$ \\
\hline 17 & Sylviidae & Prinia inomata & White-browed Prinia & $\mathrm{LC}$ & $\mathrm{Br}$ \\
\hline 18 & Turdidae & Copsychus saularis & Magpie Robin & $\mathrm{LC}$ & br \\
\hline 19 & Estrildidae & Lonchura punctulata & Scaly-breasted Munia & LC & $\mathrm{Br}$ \\
\hline 20 & Dicruridae & Dicrurus caerulescens & White bellied Drongo & $\mathrm{LC}$ & $\mathrm{Br}$ \\
\hline 21 & Pycnonotidae & Pycnonotus cafer & Red-vented bulbul & LC & $\mathrm{Br}$ \\
\hline 22 & Psittaculidae & Psittacula krameria & Rose-ringed parakeet & LC & $\mathrm{Br}$ \\
\hline 23 & Megalaimidae & Psilopogon zeylanicus & Brown-headed Barbet & LC & $\mathrm{Br}$ \\
\hline 24 & Phalacrocoracidae & Microcrabo niger & Little comorant & LC & $\mathrm{Br}$ \\
\hline
\end{tabular}

LC-Least Concern, Br-breeding resident.

\section{Discussion}

Main objective of the present study was to document the avifaunal diversity of the Crow Island Beach Park. During the study period of two months (July to August) found 30 bird species from the 7 ha of the park, this number may be 
more than this during the Migratory period (August to April) of the birds. All the bird species found in the Beach park during the study period are listed as least concern in the Red Data Book (IUCN 2012) [13]. For the selected wetlands from Colombo district namely Beddagana, Talangama, Diyasaru park, Diyatha Uyana and weli Park, Field Ornithology Group of Sri Lanka (FOGSL) has done a pilot project to identify the local and migrant bird species and they recorded 92 bird species from these wetland areas including 05 endemic species (Colombo wetland birds, 2018) [14]. Crow Island coastal wetland alone has 30 species and it can be increased with the migratory species during migratory period of August to April season. Research on spatial variation of waterbirds in Northern province of Sri Lanka by Kandasamy et al. (2017) [10] recorded 50 bird species belonging to 15 families in the study area in contrast to the present study which recorded nine species belonging to five families of water birds. The high environmental heterogeneity of coastal lagoons provides habitats for waterbirds. In Sri Lanka, most of the coastal waterbirds are migrants. Subsequently there may be more bird species in this coastal wetland during the migratory period.

Even though this beach park is small in size and urbanized when compared to other coastal wetlands it has high number of bird species. Beach park consists of a variety of habitats including grasslands, open grounds, mangrove and swamp area, scrub forest, commercial area and waterbody. The mosaic nature yields multiple habitat edges enriched with many microhabitats features suitable for different species (Cramer and Willig, 2005) [15]. Beach park is significantly rich in resources availability for the birds. For instance, fruit-bearing plant species and multiple habitats provide abundant niches and microhabitat conditions for invertebrates and brackish water habitats which provide food for water birds. Hence beach park provides plenty of food for different feeding guilds of birds.

In this study, noted that scrub forests had the highest avifaunal diversity followed by mangrove and swamp area. However, Shahabuddin and Kumar (2006) [16] found that bird diversity is significantly low in disturbed habitats. This discrepancy can be explained with the intermediate disturbance hypothesis which states that species diversity is highest when disturbances are moderate in intensity and frequency (Connell, 1978) [17]. Since this beach park is a coastal wetland it is important to spectator the water birds that live in the area. According to Henry (1998) [18], waterbirds recorded in Sri Lanka belong to the following families: Podicipedidae, Phalacrocoracidae, Anhingidae, Pelecanidae, Ardeidae, Ciconiidae, Threskiornithidae, Phoenicopteridae, Anatidae, Rallidae, Jacanidae, Rostratulidae, Haematopodidae, Recurvirostridae, Dromadidae, Burhinidae, Glareolidae, Charadriidae, Scolopacidae, Laridae and Sternidae subsequently from that 21 families of birds, five families namely Phalacrocoracidae, Pelecanidae, Ardeidae, Rallidae, Charadriidae can be seen in the Crow Island beach park.

In spite of being human manipulated, the beach park is relatively safe from threats that endanger avifauna. During study noted significant extents of habitat destruction and modification. Residents use the grassland area for cattle feeding 
and set fire to collected garbage close to the grassland and scrub forest area. drastic declines of grassland will destroy the nests of many ground and undershrub nesters such as prinias, munias and babblers.

\section{Conclusion}

Preliminary study of the avifaunal diversity of Crow Island beach park revealed that this coastal wetland is a suitable habitat for variety of birds including waterbirds. This might be due to different type of habitats in one place as well as availability of food and shelter in the area. This park also can be used for bird watching for local urban community inhabited in Colombo. During observed period, a lot of birds come to rest in the foliage close to mangrove swamp area for the night. Crow Island is urbanized wetland and modified one due to Metro Colombo urban development project, but still because of the scrub forest, mangrove swamp and the grass land, it is suitable for the avifaunal diversity. Further studies should be targeted on ecology, especially reproductive biology, population dynamics and health of birds of the beach park including migratory species. For efficient management and conservation of avifauna, a comprehensive knowledge on the ecology and the life histories of the birds are required. With such information, as well as one objective of the study was to give recommendation to manage the habitats of the beach park more appropriately to enhance the resource availability and habitat suitability for different species of birds which in turn will improve the long-term viability of assemblage of avifauna in the Crow Island beach park coastal wetland.

\section{Acknowledgements}

I wish to acknowledge Colombo Municipal Council for their permission to do this survey in the urban public park. In addition, I wish to express my gratitude towards the reviewers who have given their remarks on the paper.

\section{Conflicts of Interest}

The authors declare no conflicts of interest regarding the publication of this paper.

\section{References}

[1] Gunatilleke, N., Pethiyagoda, R. and Gunatilleke, S. (2008) Biodiversity of Sri Lanka. Journal of the National Science Foundation of Sri Lanka, 36, 25-61. https://doi.org/10.4038/jnsfsr.v36i0.8047

[2] Ramsar Convention Bureau (1997) The Ramsar Convention Manual: A Guide to the Convention on Wetlands (Ramsar, Iran, 1971). 2nd Edition, Ramsar Convention Bureau, Gland.

[3] National Wetland Directory of Sri Lanka (2006) IUCN Sri Lanka and the Central Environmental Authority. Colombo.

[4] The Ramsar Convention Secretariat (2018) 18 Cities Recognized for Safeguarding Urban Wetlands. 
https://www.ramsar.org/news/18-cities-recognized-for-safeguarding-urban-wetland s

[5] Hettiarachchi, M., Morrison, T., Wickramasinghe, D., Mapa, R., de Alwis, A. and Mcalpine, C. (2014) The Eco-Social Transformation of Urban Wetlands: A Case Study of Colombo, Sri Lanka. Landscape and Urban Planning, 132, 55-68. https://doi.org/10.1016/j.landurbplan.2014.08.006

[6] IUCN Sri Lanka (2004) Wetland Conservation in Sri Lanka. Proceedings of the National Symposium on Wetland Conservation and Management, Colombo, 19-20 June 2003, iii+75.

[7] (2014) Environmental Screening Report for the Proposed Beach Park at Crow Island, Metro Colombo Urban Development Project (MCUDP), Project Management Unit Metro Colombo Urban Development Project Ministry of Defence and Urban Development. Final Report.

[8] Kotagama, S.W., De Silva, R.I., Wijayasinha, A.S. and Abeygunawardena, V. (2006) Avifaunal List of Sri Lanka. In: Bambaradeniya, C.N.B., Ed., Fauna of Sri Lanka: Status of Taxonomy, Research and Conservation, The World Conservation Union, Colombo, 164-203.

[9] Kaluthota, C.D. and Kotagama, S.W. (2008) Historical Changes in Number of Endemic Birds in Sri Lanka from 1852 to 2006. Annual Forestry and Environment Symposium, Colombo, January 2008, 70 p.

[10] Kandasamy, G., Weerakoon, D.K. and Sivaruban, A. (2017) Spatial Variation of Waterbirds in Pallai and Thadduvankoddy in the Northern Province, Sri Lanka. Third International Conference on Science, Engineering \& Environment (SEE), Brisbane, 13-16 November 2017, 124-129.

[11] Kandasamy, G., Weerakoon, D.K., Sivaruban, A. and Jayasiri, H.B. (2019) Community Structure of Waterbirds in Thadduvankoddy, Kapputhu and Nagarkovil in the Northern Region of Sri Lanka. Proceedings of the Vavuniya Campus International Research Symposium, Vavuniya, October 2019, 124-130.

[12] Harrison, J. andWorfolk, T. (1999) A Field Guide to the Birds of Sri Lanka. Oxford University Press, Oxford, 219 p.

[13] IUCN (2012) The National Red List 2012 of Sri Lanka. In: Weerakoon, D.K. and Wijesundara, S., Eds., Conservation Status of the Fauna and Flora, Ministry of Environment, Colombo, 114-120.

[14] Colombo Wetland Birds (2018) The GEF Small Grants Programme. Field Ornithology Group of Sri Lanka, Department of Zoology and Environment Science, University of Colombo, Colombo.

[15] Cramer, M.J. and Willig, M.R. (2005) Habitat Heterogeneity, Species Diversity and Null Models. Oikos, 108, 209-218. https://doi.org/10.1111/j.0030-1299.2005.12944.x

[16] Shahabuddin, G. and Kumar, R. (2006) Influence of Anthropogenic Disturbance on Bird Communities in a Tropical Dry Forest: Role of Vegetation Structure. Animal Conservation, 9, 404-413. https://doi.org/10.1111/j.1469-1795.2006.00051.x

[17] Connell, J.H. (1978) Diversity in Tropical Rain Forests and Coral Reefs. Science, 199, 1302-1310. https://doi.org/10.1126/science.199.4335.1302

[18] Henry, G.M. (1998) A Guide to the Birds of Sri Lanka. Third Edition, KVG de Silva and Sons (Kandy), Colombo, Oxford University Press, Oxford. 